\title{
UNRWA: 0 Compromisso Da Sociedade Internacional Com Os Refugiados \\ Palestinos
}

\author{
Claudia Stephan 1
}

\section{RESUMO}

A criação da Agência de Socorro e Obras Públicas das Nações Unidas para os Refugiados Palestinos no Oriente Próximo (UNRWA) foi resultado da necessidade de atender aos refugiados palestinos oriundos do Conflito Árabe-Israelense de 1948, quando da criação do Estado de Israel na Palestina. Porém, 63 anos depois, seu assistencialismo ainda é vital.

Palavras-chave: UNRWA; Conflito Árabe-Israelense; Refugiados Palestinos.

A Agência de Socorro e Obras Públicas das Nações Unidas para os Refugiados Palestinos no Oriente Próximo ${ }^{2}$ (UNRWA), subsidiária da Organização das Nações Unidas (ONU), foi criada para atender aos refugiados palestinos oriundos do Conflito Árabe-Israelense de 1948, consequência da fundação do Estado de Israel na Palestina.

À época, havia o compromisso, expresso na Declaração de Balfour ${ }^{3}$, de que os habitantes daquela região não seriam abandonados à própria sorte. Mas o decorrer dos fatos provou exatamente o contrário, a necessidade de uma agência focada nos refugiados palestinos foi percebida pela sociedade internacional devido ao crescente número desses refugiados, desde o início do Conflito Árabe-Israelense, em maio de 1948. Com 77,4\% do território palestino ocupado por Israel, aproximadamente 700.000

\footnotetext{
1 Claudia Stephan é internacionalista, especialista em Sociologia Política, mestranda pelo Programa de Pós-Graduação Stricto Sensu em Ciência Política na Universidade Federal do Paraná (UFPR) e pesquisadora do Núcleo de Estudos e Pesquisas em Relações Internacionais (NEPRI/UFPR).

2 UNRWA é a sigla da agência em Inglês. Não há sigla em Português.

${ }^{3}$ A Declaração de Balfour expressava a simpatia britânica pela causa sionista e os futuros esforços para a constituição de um "lar nacional judeu" na Palestina, desde que fossem respeitados os direitos políticos e religiosos da população não judaica da região (BALFOUR, 1917 apud STEPHAN, 2009, p.29). 
mil palestinos se encontravam na condição de refugiados em 1949 (TAKKENBERG, 2010, p.254).

A UNRWA foi então criada a partir de uma Resolução da Assembleia Geral da ONU, a Res. 302(IV)4 ${ }^{4}$ em 08 de dezembro de 1949. Suas atividades tiveram início em $1^{\text {o }}$ de maio de 1950, através do sistema de mandatos, renováveis a cada três anos (UNRWA, 2012, s/n). Inicialmente, em caráter temporário, a agência ficou encarregada de prestar assistência aos refugiados palestinos, via programas educacionais e socioeconômicos, até que a questão fosse solucionada (GING, 2010, p.1).

Segundo a UNRWA, são considerados refugiados palestinos

\begin{abstract}
pessoas que tinham como seu local de residência a Palestina entre Junho de 1946 e Maio de 1948, que perderam tanto suas casas quanto seus meios de sobrevivência como resultado do Conflito Árabe-Israelense de 1948. [...]Os serviços da Agência de Socorro e Obras Públicas das Nações Unidas para os Refugiados Palestinos no Oriente Próximo estão disponíveis para todos os residentes das áreas de operação que se encaixam na definição de refugiados, e que estão registrados na agência e precisam de assistência. Os descendentes dos palestinos refugiados também podem se registrar (UNRWA, 2012, s/n tradução livre).
\end{abstract}

Em 1950, os refugiados palestinos registrados somavam 914,221 mil. Passadas três décadas, em 1980, esse número aumentou para 1.844,318 milhão de refugiados, e, em apenas uma década (1990), aumentou para 2.422,514 milhões, atingindo os 4.618,141 milhões de refugiados palestinos em 2008 - ano final da pesquisa (UNRWA, 2008, s/n). Atualmente, o número de refugiados palestinos é de 5.115,755 milhões, de acordo com o mais recente relatório da agência (UNRWA, 2012, p.1).

A UNRWA opera com doações voluntárias dos países membros da ONU para auxiliar os refugiados palestinos, oferecendo assistência, proteção, bem como representando a causa internacionalmente. Sua área de atuação específica é o Oriente Próximo - ou também chamado de Oriente Médio, na Jordânia, na Síria, no Líbano e nos territórios ocupados da Palestina - Cisjordânia e Faixa de Gaza (UNRWA, 2012, s/n).

\footnotetext{
${ }^{4}$ Para acessar a Resolução 302(IV) da Assembleia Geral da ONU de 1949: http://www.un.org/ga/search/view_doc.asp?symbol=A/RES/302(IV)\&Lang=E\&Area=RESOLUTION Conjuntura Global, Curitiba, Vol. 1, n.2, out./dez., 2012, p. 41-44.
} 
A UNRWA tem um escritório em cada campo de refugiados, que serve para manter o registro dos dados e também atualizá-los, assim como serve de intermediário entre os refugiados e a própria agência. São oferecidos serviços educacionais, de saúde e centros de distribuição, através de instalações da agência nos próprios campos ou em seus arredores, nas áreas em que há maior concentração de refugiados palestinos (UNRWA, 2012, s/n).

É importante ressaltar que a UNRWA é uma agência estritamente humanitária, que não administra os campos de refugiados ${ }^{5}$, nos quais atua, e trabalha com o princípio da neutralidade; portanto, não tem autoridade para negociar ou resolver a questão dos refugiados. 0 mandato original da agência previa:

executar programas de assistência direta e obras públicas em colaboração com os governos locais, consultar com os governos do Oriente Próximo em relação às medidas a serem tomadas em preparação para a hora em que projetos de assistência internacional não sejam mais necessários, e planejar para o momento em que o socorro não fosse mais necessário (UNRWA, 2012, s/n tradução livre).

O mandato contemporâneo da UNRWA prescreve serviços de assistência, desenvolvimento humano e proteção para os refugiados palestinos e pessoas deslocadas pelas hostilidades de 19676, em suas áreas de operação. 0 último foi renovado até 30 de junho de 2014 (UNRWA, 2012, s/n).

A priori, em caráter temporário, via mandatos de três anos, o trabalho humanitário da UNRWA perdura até hoje. Enquanto os palestinos não tiverem seu próprio Estado, para que a questão dos refugiados seja negociada e resolvida permanentemente, a assistência da agência é imprescindível. Da mesma maneira, enquanto a sociedade internacional transferir sua responsabilidade aos próprios palestinos, uma solução permanente para o conflito parece estar distante.

\footnotetext{
5 Os campos de refugiados são operados pelo Alto Comissariado das Nações Unidas para os Refugiados (ACNUR), em parceria com os governos locais.

${ }^{6}$ Em referência à Guerra dos Seis Dias, em 1967, quando Israel ocupou a Península do Sinai, a Faixa de Gaza, a Cisjordânia e as Colinas de Golã em 1967. 
Assim, a UNRWA continua a assumir o compromisso estabelecido pela sociedade internacional, via Nações Unidas (ONU), de assistir aos refugiados palestinos, enquanto aguardam uma solução permanente, após 63 anos de sua criação.

\section{Referências Bibliográficas}

GING, John. 60 Years of Partnership for Palestinian Rights: UNRWA and Palestine Refugees. Conference paper. Berlin, 8 March 2010. Disponível em: <http://www.boell.de/downloads/Dossier_Palaestine_Session1_Conference_Paper_ John_Ging_08032010.pdf>. Acesso em: 16/05/2012.

STEPHAN, Claudia. Hizbullah: a importância do movimento de resistência islâmico para as negociações de paz árabe-israelenses. TCC: Relações Internacionais - Setor de Ciências Sociais Aplicadas. 106 fls. Universidade Tuiuti do Paraná. 2009. Disponível em: http://www.ibeipr.com.br/conteudo/academicos/claudiastephan.pdf Acesso em: 24 novembro 2012.

TAKKENBERG, L. (Guest Editor). UNRWA and the Palestinians Refugees after Sixty Years: Some Reflections. Refugee Survey Quarterly, vol. 28, n. 2 \& 3, 2010. Disponível em: <http://www.unrwa.org/userfiles/20100610957.pdf>. Acesso em: $10 / 10 / 2011$.

UNRWA - History and Establishment of UNRWA. Disponível em: <http://www.unrwa.org/etemplate.php?id=87\#history>. Acesso em: 05 outubro 2010.

UNRWA - (2012). Overview Disponível em: <http://www.unrwa.org/etemplate.php?id=85>. Acesso em: 10/10/2011.

UNRWA - Statistics (as of 1 January 2012). Disponível em: <http://www.unrwa.org/etemplate.php?id=253>. Acesso em: 28/04/2012.

UNRWA Statistics - Number of registered refugees (1950 - 2008). Disponível em: <http://www.unrwa.org/userfiles/reg-ref(2).pdf>. Acesso em: 15/05/2012. 